PRINT ISSN 1119-8362

Electronic ISSN 1119-8362
Full-text Available Online at

https://www.ajol.info/index.php/jasem

http://ww.bioline.org.br/ja
J. Appl. Sci. Environ. Manage.

Vol. 24 (2) 393-401 February 2020

\title{
Effects of Solid Waste Disposal on the Receiving Soil Quality in Benin Metropolis, Nigeria
}

\author{
*1, 2,3 SAM-UROUPA, ER; ${ }^{3}$ OGBEIBU, AE \\ ${ }^{1}$ Edo State Ministry of Environment and Sustainability, Benin City \\ ${ }^{2}$ Edo State Oil and Gas Producing Areas Dev. Commission, Benin City \\ ${ }^{3}$ Department of Animal and Environmental Biology, Faculty of Life Sciences, University of Benin, Ugbowo, Benin City PMB 1154, Nigeria \\ *Corresponding Author Email: ewerericher@yahoo.com
}

\begin{abstract}
The present study investigated the impact of solid waste disposal on the receiving soil quality of four major dump-sites and a control site in Benin Metropolis, Edo State, Nigeria by collecting samples at three distances from the dump-sites of $0-50 \mathrm{~m}, 50-100 \mathrm{~m},>100 \mathrm{~m}$ at $0-30 \mathrm{~cm}$ depth. The investigation spanned from July 2011 to December 2011. Results obtained during these months were pooled together to obtain single mean for each sampling station or distance. Results showed that $\mathrm{pH}$ values ranged between 5.23 and 5.83, recording slight variations from one site to the other, with no significant differences $(\mathrm{P}>0.05)$ across the study stations and distances. Electrical conductivity concentrations ranged from $562.00-982.33 \mu \mathrm{S} / \mathrm{cm}$, with the highest concentrations recorded at $0-50 \mathrm{~m}$, whereas concentrations were lowest beyond $100 \mathrm{~m}$. Significant increased concentrations of heavy metals $(\mathrm{Fe}, \mathrm{Mn}, \mathrm{Zn}, \mathrm{Cu}, \mathrm{Cr}, \mathrm{Pb}, \mathrm{Ni}$ and $\mathrm{V}$ ) were reported when compared with the control. The bacterial count $(\mathrm{F}=7.527$, $\mathrm{df}=3)$ and fungal count $(\mathrm{F}=5.749, \mathrm{df}=3)$ of soil sample did not show a significant difference $(\mathrm{P}>0.05)$ between the test stations and the control station respectively, although the mean ranks were highest in the control station.
\end{abstract}

DOI: https://dx.doi.org/10.4314/jasem.v24i2.27

Copyright: Copyright $(2020$ Sam-Uroupa and Ogbeibu. This is an open access article distributed under the Creative Commons Attribution License (CCL), which permits unrestricted use, distribution, and reproduction in any medium, provided the original work is properly cited.

Dates: Received: 16 November 2019; Revised: 11 January 2020; Accepted: 22 February 2020

Keywords: Benin City, dump sites, Ikhueniro, soil quality, municipal waste

Waste is anything which is no longer useful to the disposer. It can likewise be characterized as any unavoidable material resulting from an action or process, which has no prompt economic interest and which must be discarded (NISP, 2003). Waste can be liquid, gaseous or solid, depending on its state. Solid waste implies undesirable materials or substances that are left or disposed of after use, additionally including side-effects of procedure lines or materials that might be legally necessary to be discarded (Okecha, 2000). They can be characterized in various manners; based on source, ecological dangers, utility and physical property. The creation of waste by man is unavoidable (Ogbeibu et al., 2013). Humanity is delivering more refuse than any time in recent history, creating problems for nature. Increase in population combined with expanding industrialization and aimless waste removal has prompted enormous volume of waste found in our surroundings today. Wastes and strategies for disposing of them cause a ton of environmental problems particularly when they are not appropriately disposed of. Frequently, the manner in which individuals discard their waste is to just drop it in some spot. Open, unregulated dumps are as yet the technique for waste removal in most developing nations; even the third world mega cities have waste problems. Most waste dumps are indiscriminately placed at common sites in developing countries. In these countries, the use of waste dump as an ideal system of waste management and disposal is common practice (Achudume and Olawale, 2007). As wastes accumulate on a particular site, a couple of physicochemical as well as biological processes occur within and around its surrounding environment. Assemblage of myriads of microbial pathogens of all kinds takes place. In very many cases, heavy metal seepages into soil and possible accumulation on groundwater is not farfetched. Altogether, humans are at the receiving end.

People are usually connected to the common site of waste disposal, especially those residing within the locality of such dumpsites. Incidence of occurrence and concentration of microbial pathogens may fluctuate from place to place but such fluctuations could not present public health hazard.

It is important to note that the soil is a principal recipient of solid waste. These wastes interact with the soil system thus altering the physicochemical properties (Piccolo and Mbagwu, 1997). According to Anikwe (2000), waste amended soils have high 
content of organic matter. Soil organic matter influences the degree of aggregation and aggregate stability (Mbagwu and Piccolo, 1990) and also, can reduce bulk density and increased total porosity and hydraulic conductivity in heavy clay soils, but the magnitude of increase depends on the rate of application (Anikwe, 2000 and Mbagwu, 1989).

A number of significant impact of solid wastes in soils have been conducted previously, including rise in nitrogen, $\mathrm{pH}$, cation exchange capacity, percentage base saturation and organic matter (Anikwe and Nwobodo, 2001). However, excessive waste in soil may increase heavy metal concentration in the soil and underground water. Heavy metals may have harmful effects on soils, crops and human health, (Smith et al., 1996). As a result of the adsorptive and buffering properties of soils, some pollutants have long halflives in the soil. Therefore, food crops grown on these polluted soils may be affected by some of the pollutants for centuries even millennia because soil is difficult and expensive to cleanup (Alloway and Ayres, 1997). The aim of the study therefore is to investigate soil quality of three popular municipal waste dump sites in Benin City.

\section{MATERIALS AND METHODS}

The study area: Benin metropolis is made up of five Local Government Areas of Oredo, Egor, IkpobaOkha, Ovia North-East and Uhunmwonde and it is the capital of Edo State, Nigeria. It lies between latitudes $6^{\circ} 16^{\prime} \mathrm{N}$ to $6^{\circ} 33^{\prime} \mathrm{N}$ and longitudes $5^{\circ} 31^{\prime} \mathrm{E}$ to $5^{\circ} 45^{\prime} \mathrm{E}$ (Figure 1) (Nkeki, 2013). The areas of study are the solid waste dump-sites. The sample location encompassed Ikhueniro (bypass) with a geographic coordinate of $06^{\circ} 19^{\prime} 39.3^{\prime \prime} \mathrm{N}$ and $005^{\circ} 44^{\prime} 45.9^{\prime \prime} \mathrm{E}$ (elevation $88 \mathrm{~m}$ ); Costain (New Benin) 06 $26^{\circ} 50.0^{\prime \prime} \mathrm{N}$ and $005^{\circ} 38^{\prime}$ 16.4"E (elevation 76m); Ugbiyoko (Ekenwan) $06^{\circ} 17^{\prime} 39.28^{\prime \prime} \mathrm{N}$ and $005^{\circ} 32^{\prime} 45.78^{\prime \prime} \mathrm{E}$ (elevation 66m); Omaghe (Sapele Road) $06^{\circ} 18^{\prime}$ $40.6^{\prime \prime} \mathrm{N}$ and $005^{\circ} 38^{\prime} 13.8^{\prime \prime} \mathrm{E}$ with elevation of $88 \mathrm{~m}$ (Figure 2).

Description of the study stations: Four stations were chosen for this study from four different Local Government Areas with each station at one Local Government Area. The stations understudy were Ikhueniro dump-site, the dump-site at Costain, dumpsite at Ugbiyoko and Omaghe, which was used as the control station was void of waste dump-site.

Station 1 (Ikhueniro Waste Dump-site): The Ikhueniro dump-site is an approved waste dump-site by the Edo State Government and managed by Edo State Waste Management Board. It is located along the BeninLagos bypass in Uhunmwonde Local Government
Area of Edo State. It was an excavated site/burrow pit which was later converted into waste dump-site and has been in use for over 20years.

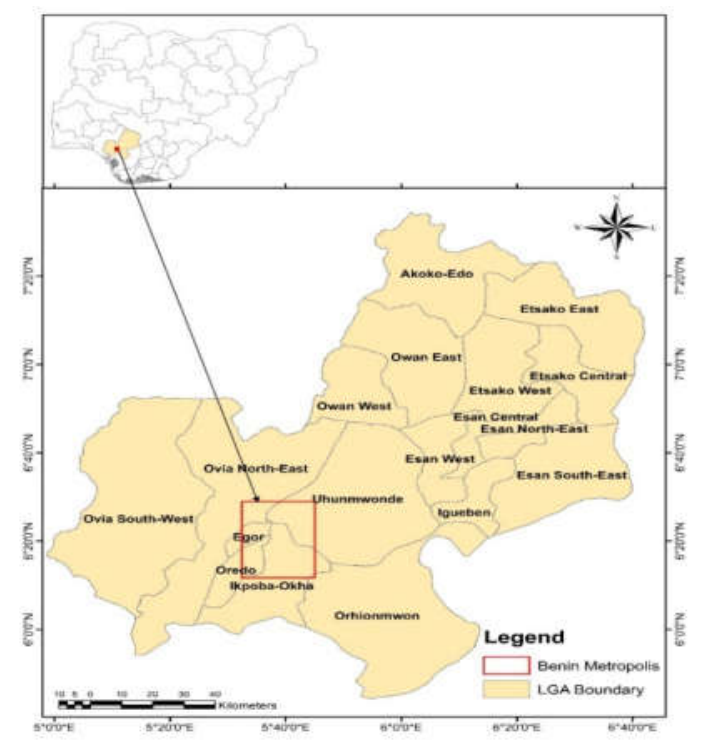

Fig 1: Administrative map of Edo State showing the limit of Benin Metropolis

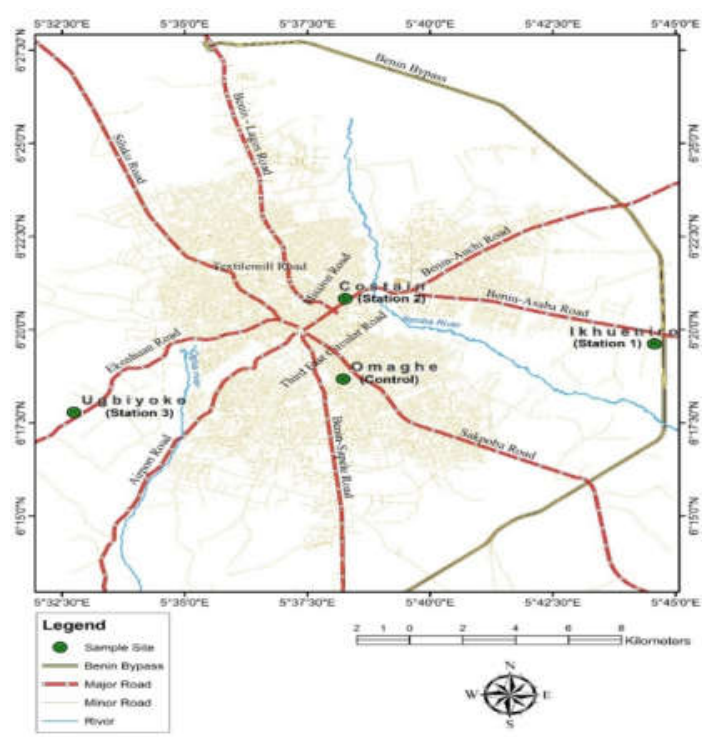

Fig 2: Map of Benin Metropolis showing the Sample Sites

Domestic, market, agricultural, hospital and industrial wastes, sewage and sludge including construction wastes are the commonest kind of waste found in this government approved dump-site. Quite often, wastes are spread across more than $90 \%$ of the land mass especially during the raining season when the vehicles have no access to the inner part of the dump-site as a result of poor management, thereby leading to 
indiscriminate dumping by waste managers/trucks. Once a while, the waste dump-site receives attention by a bail loader coming around to push the overflowing waste into the pit. Close to this dump-site are residential homes, pure water factory, commercial buildings and farmlands. This dump-site spans over $150 \mathrm{~m}$. A residential borehole located at a distance $>100 \mathrm{~m}$ from this dump-site was sampled for this research work. Soil samples were taken from around this vicinity at $0-50 \mathrm{~m}, 50-100 \mathrm{~m}$ and $>100 \mathrm{~m}$ distances from the dump-sites at a depth of $0-30 \mathrm{~cm}$.

Station 2 (Costain Waste Dump-site): The station at Costain is an illegal waste dump-site located in Oredo Local Government Area of Edo State. This dump-site which was formerly a monument to the Bini's (a moat), has been illegally patronized by waste managers, private companies and individuals for over 20years in dumping of various kinds of wastes. Domestic, market, agricultural, industrial, hospital wastes including sewage and sludge are the types of solid waste found in this dump-site. Residential homes, commercial buildings, factories with high population of people live in this area. This dump-site spans over $110 \mathrm{~m}$. A residential borehole located at a distance $<60 \mathrm{~m}$ from this dump-site was sampled for this research work. Soil samples were taken from around this vicinity at $0-50 \mathrm{~m}, 50-100 \mathrm{~m}$ and $>100 \mathrm{~m}$ distances from the dump-sites at a depth of 0-30 cm.

Station 3 (The Waste Dump-site at Ugbiyoko): The Dump-site at Ugbiyoko is also an illegal waste dumpsite located in Egor Local Government Area of Edo State. This area which was formerly a moat i.e. a monument to the Binis, has over the years be turned into a waste dump-site. This illegal dump-site has been in use for over 10 years. The common types of waste found in the dump-site are domestic, market, agricultural waste. Also, this waste dump-site is very close to farms, residential homes and a market. This dump-site spans over $65 \mathrm{~m}$. A community borehole located at a distance $<50 \mathrm{~m}$ from this dump-site was sampled for this research work. Soil samples were taken from around this vicinity at 0-50 m, 50-100 m and $>100 \mathrm{~m}$ distances from the dump-sites at a depth of $0-30 \mathrm{~cm}$.

Station 4 (Omaghe - The Control Station): Omaghe is a settlement located in Ikpoba-Okha Local Government Area of Edo State. This station is void of any waste dump site. This station is a highly populated residential area and it is therefore used as the control to this study. The distance of the control station from any of the waste dump-sites mentioned above is $>1 \mathrm{~km}$. Soil samples were taken at $0-50 \mathrm{~m}, 50-100 \mathrm{~m}$ and
$>100 \mathrm{~m}$ distances from the borehole at a depth of 0 $30 \mathrm{~cm}$.

Sampling periodicity and procedure: Soil samples were collected using soil auger at varying distances from each of the dump-sites and the control station from $0-30 \mathrm{~cm}$ depth of top soil. The distances from the dump-sites and the borehole point (control) were 0$50 \mathrm{~m}, 50-100 \mathrm{~m}$ and $>100 \mathrm{~m}$ respectively. This was done at the very first month of the sampling period which was in July, 2011. Three soil samples were collected per station and put into polythene sample bags and labeled accordingly. A total of twelve soil samples were collected during the monitoring visit in July, 2011. These were carried out to determine the original status of the soils sampled. All soil samples were collected between the hours of $7 \mathrm{a} . \mathrm{m}$. and $11 \mathrm{a} . \mathrm{m}$.

Physicochemical Analysis of Soil Samples: Following the methods of SSSA (1971); AOAC (1999); APHA (2008); Zhang et al. (2010), physicochemical parameters analyzed includes; $\mathrm{pH}$, electrical conductivity, chlorine, Sulphate, Nitrate, Phosphate, Ammonium nitrogen, Calcium, Magnesium, Sodium, Potassium, Zinc, Copper, Chromium, Lead, Manganese, Iron, Nickel, moisture content, total organic carbon content and total nitrogen.

Identification of Soil Microorganisms: Enumeration of bacterial and fungi counts were conducted according to methods prescribed by Cowan and Steel (1974), Cheesbrough (2001) and Taiwo and Oso (2004).

Statistical analysis: Besides the basic statistical measurements of central tendency and dispersion to characterize the stations in terms of the physicochemical conditions, inter-station comparisons were carried out to test for significant differences in physicochemical conditions and microbial assay using One-way Analysis of Variance (ANOVA) tests. Test of significance for soil and water microbial assay across the distance was carried out using nonparametric; Kruskal-Wallis $(\mathrm{H})$ test. If significant ' $\mathrm{H}$ ' values $(\mathrm{P}<0.05, \mathrm{P}<0.01, \mathrm{P}<0.001)$ were obtained, Duncan Multiple Range (DMR) tests were performed to determine the source of significant differences. The statistical packages used include SPSS (version 17.0) and Microsoft Excel 2010 statistical tool pack. Graphical presentations were also carried out using Microsoft excel.

\section{RESULTS AND DISCUSSION}

The soil is the most important life-support the earth's ecosystem. This is predicated on the fact that most of the ecosystem rely on the ability of plants to harness energy from the sun and convert into biochemical 
forms necessary for metabolism and also balance in the ecosystem. The soil is important as a necessary anchorage for terrestrial plants apart from the fact that it is a source of important nutrients necessary for growth and development of the plants. According to Wild (1995), soil acts as filter for drinking water and sink for pollutants. The implication of concentration of the latter and subsequent exposure to plants is the very reason these plants become impaired in the growth and development; this eventually turns back to hunt heterotrophic components of the ecosystem. The current study investigated impact municipal waste dumps on the receiving soil quality. It was also important to understudy possible variability in soil characteristics basd on distances of sampling as well as on sampling stations.

Tables 1 and 2 showed the comparison of mean values for physical and chemical properties of soil sampled across the four stations and across the three distances using one -way analysis of variance respectively for the month of July 2011 in Benin Metropolis. The entire soil from the study stations was moderately acidic.

From the results obtained, the hydrogen ion concentration $(\mathrm{pH})$ mean values ranged between 5.23 (Station 1) and 5.83 (Station 2) recording slight variations from one site to the other. The values recorded were below criteria of UNEP with no significant differences $(\mathrm{P}>0.05)$ across the study stations and distances but it was highest in station 2 and a distance of $0-50 \mathrm{~m}$ from the dump-sites. The results showed that the soils sampled at the beginning of the analysis were moderately acidic, a typical characteristic of tropical soils in line with the work of Gasu and Ntemuse (2011) which can increase the concentration of metals in the soil solution. Hydrogen ion concentration levels that are acidic tend to have an increased micro-nutrient solubility and mobility as well as increased heavy metal concentration in soil (Ogbonna et al., 2009) thus rendering the soil unsuitable for waste land filling.

For electrical conductivity, Station 1 recorded the highest mean concentration $(982.33 \mu \mathrm{S} / \mathrm{cm})$ while station 4 recorded the lowest mean concentration $(562.00 \mu \mathrm{S} / \mathrm{cm})$ across the four sampled stations. Across the three distances, $0-50 \mathrm{~m}$ had the highest concentration $(712.50 \mu \mathrm{S} / \mathrm{cm})$ while $>100 \mathrm{~m}$ recorded the lowest mean concentration $(675.50 \mu \mathrm{S} / \mathrm{cm})$. The one-way analysis of variance was used to examine the difference in means.

A highly significant difference was obtained $(\mathrm{P}<0.001)$ across the stations. A posteriori DMR test revealed that station 1 was highly significant from station 2, while 3 and 4 which were not different from each other were the lowest. Across the distances, there was no significant difference $(\mathrm{P}>0.05)$. The highly significant value $(\mathrm{P}<0.001)$ across the stations indicated decomposition (Ideriah et al., 2006) of the waste material since much of the humic substances was contributed by organic waste. Electrical Conductivity is a technical term used to indicate the saltiness of a material. The mean electrical conductivity was highest at a distance of $0-50 \mathrm{~m}$ which showed that most of the organic decomposition took place at a distance closest to the dump-site, although there was no significant difference $(\mathrm{P}>0.05)$ across the study distances. This is in line with the observations and activities which take place at the dump-sites in which population explosion and increased rate in the waste generation have increased the dimensions of waste dump-sites to distances $>100 \mathrm{~m}$. Prior to this time at station 1 , wastes were dumped within the distance of $0-50 \mathrm{~m}$ from the point of excavation of the pit/moat.

The mean values of chloride are presented in Tables 1 and 2. Stations 1 and 4 showed the highest $(630 \mathrm{meq} / 100 \mathrm{~g})$ and lowest $(287 \mathrm{meq} / 100 \mathrm{~g})$ mean values respectively. A highly significant difference ( $\mathrm{P}$ $<0.001$ ) was obtained. A posteriori DMR revealed that station 1 was highly significant from station 2 while stations 3 and 4 which were not different from each other were the lowest. $>100 \mathrm{~m}$ and $50-100 \mathrm{~m}$ recorded the highest $(426 \mathrm{meq} / 100 \mathrm{~g})$ and lowest $(424 \mathrm{meq} / 100 \mathrm{~g})$ mean values respectively. There was no significant difference $(\mathrm{P}>0.05)$ in the mean values of chloride across the distances of the study stations. Stations 1and 4 showed the highest $(17.90 \mathrm{mg} / \mathrm{kg})$ and lowest $(14.63$ $\mathrm{mg} / \mathrm{kg}$ ) mean values respectively. There was a highly significant difference $(\mathrm{P}<0.001)$ in the values obtained. A posteriori DMR test showed that station 1 was highly significant from station 2 , while 3 and 4 which were not different from each other were the lowest. $0-50 \mathrm{~m}$ and $50-100 \mathrm{~m}$ distances recorded the highest $(16.18 \mathrm{mg} / \mathrm{kg})$ and lowest $(15.98 \mathrm{mg} / \mathrm{kg})$ mean concentrations respectively. There was no significant difference $(\mathrm{P}>0.05)$ across the study distances when tested with one-way analysis of variance.

The variation pattern of soil in available phosphorus and total nitrogen are shown. Stations 1 and 3recorded the highest $(20.77 \mathrm{mg} / \mathrm{kg})$ and lowest $(14.72 \mathrm{mg} / \mathrm{kg})$ mean values for available phosphorus while stations land 4 were the highest $(0.14 \%)$ and lowest $(0.11 \%)$ for total nitrogen respectively. A highly significant difference $(\mathrm{P}<0.001)$ and $(\mathrm{P}<0.01)$ were observed across the sampled stations for available phosphorus and total nitrogen respectively when tested with oneway analysis of variance. 
Effects of Solid Waste Disposal on the Receiving Soil.....

397

Table 1: Comparison of mean values for physical and chemical parameters of soil sampled across the four stations in Benin metropolis using one -way ANOVA.

\begin{tabular}{|c|c|c|c|c|c|c|c|c|c|c|c|c|c|c|}
\hline \multirow[b]{2}{*}{ PARAMETER } & \multicolumn{3}{|l|}{ STATION 1} & \multicolumn{3}{|l|}{ STATION 2} & \multicolumn{3}{|l|}{ STATION 3} & \multicolumn{3}{|l|}{ STATION 4} & \multirow[b]{2}{*}{ P-VALUE } & \multirow{2}{*}{$\begin{array}{l}\text { Soil/Sediment } \\
\text { Target } \\
\text { Intervention } \\
(\mathrm{Mg} / \mathrm{kg})\end{array}$} \\
\hline & Mean \pm SE & Min & $\operatorname{Max}$ & Mean \pm SE & Min & $\operatorname{Max}$ & Mean \pm SE & Min & $\operatorname{Max}$ & Mean \pm SE & Min & $\operatorname{Max}$ & & \\
\hline $\mathrm{pH}$ & $5.23 \pm 0.09$ & 5.1 & 5.4 & $5.83 \pm 0.18$ & 5.5 & 6.1 & $5.43 \pm 0.23$ & 5.2 & 5.9 & $5.60 \pm 0.12$ & 5.4 & 6.3 & $\mathrm{P}>0.05$ & \\
\hline $\mathrm{EC}(\mu \mathrm{S} / \mathrm{cm})$ & $982.33^{\mathrm{a}} \pm 66.80$ & 860 & 1090 & $774.67^{\mathbf{b}} \pm 3.71$ & 670 & 682 & $567.00^{c} \pm 12.42$ & 540 & 593 & $562.0^{c} \pm 10.79$ & 550 & 587 & $P<0.001$ & \\
\hline Organic Carbon (\%) & $1.91^{\mathrm{a}} \pm 0.03$ & 1.87 & 1.97 & $1.71^{\mathbf{b}} \pm 0.07$ & 1.58 & 1.82 & $1.58^{\mathrm{c}} \pm 0.03$ & 1.54 & 1.64 & $1.52^{\mathrm{c}} \pm 0.02$ & 1.48 & 1.54 & $\mathrm{P}<0.001$ & \\
\hline Total Nitrogen (\%) & $0.14^{\mathrm{a}} \pm 0.00$ & 0.14 & 0.16 & $0.13^{b} \pm 0.00$ & 0.12 & 0.15 & $0.12^{\mathbf{c}} \pm 0.00$ & 0.13 & 0.14 & $0.11^{\mathrm{c}} \pm 0.01$ & 0.1 & 0.12 & $P<0.01$ & \\
\hline EA (meq/100g of soil) & $0.40 \pm 0.00$ & 0.4 & 0.4 & $0.37 \pm 0.03$ & 0.3 & 0.4 & $0.30 \pm 0.03$ & 0.2 & 0.3 & $0.27 \pm 0.03$ & 0.3 & 0.4 & $\mathrm{P}>0.05$ & \\
\hline $\mathrm{Na}$ (meq/100g of soil) & $1.35^{\mathrm{a}} \pm 0.06$ & 1.27 & 1.47 & $1.09^{b} \pm 0.08$ & 0.94 & 1.23 & $0.56^{\mathbf{c}} \pm 0.05$ & 0.48 & 0.65 & $0.49^{\mathrm{c}} \pm 0.03$ & 0.43 & 0.55 & $P<0.001$ & \\
\hline $\mathrm{K}$ (meq/100g of soil) & $0.74^{\mathrm{a}} \pm 0.00$ & 0.74 & 0.75 & $0.56^{\mathbf{b}} \pm 0.02$ & 0.54 & 0.59 & $0.57^{\mathbf{b}} \pm 0.03$ & 0.54 & 0.63 & $0.26^{\mathrm{c}} \pm 0.03$ & 0.21 & 0.32 & $P<0.001$ & \\
\hline $\mathrm{Ca}$ (meq/100g of soil) & $4.70^{\mathrm{a}} \pm 0.07$ & 4.61 & 4.83 & $4.44^{\mathrm{a}} \pm 0.06$ & 4.32 & 4.53 & $2.91^{b} \pm 0.06$ & 2.81 & 3.01 & $1.78^{\mathrm{c}} \pm 0.16$ & 1.56 & 2.1 & $\mathrm{P}<0.001$ & \\
\hline $\mathrm{Mg}$ (meq/100g of soil) & $0.69 \pm 0.03$ & 0.65 & 0.76 & $0.64 \pm 0.04$ & 0.56 & 0.68 & $0.58 \pm 0.02$ & 0.53 & 0.65 & $0.56 \pm 0.05$ & 0.56 & 0.63 & $\mathrm{P}>0.05$ & \\
\hline $\mathrm{Cl}(\mathrm{mg} / \mathrm{kg})$ & $630.00^{\mathrm{a}} \pm 26.23$ & 598 & 682 & $382.67^{\mathbf{b}} \pm 18.49$ & 350 & 414 & $327.67^{\mathrm{c}} \pm 14.19$ & 320 & 367 & $287.00^{\mathrm{c}} \pm 19.55$ & 260 & 325 & $P<0.001$ & \\
\hline Av. P (mg/kg) & $20.77^{a} \pm 0.18$ & 20.5 & 21.1 & $17.47^{\mathrm{a}} \pm 0.90$ & 16.2 & 19.2 & $14.72^{b^{b}} \pm 0.28$ & 14.22 & 15.7 & $14.74^{b} \pm 0.15$ & 14.5 & 15.01 & $\mathrm{P}<0.001$ & \\
\hline $\mathrm{NH}_{4} \mathrm{~N}(\mathrm{mg} / \mathrm{kg})$ & $17.90^{\mathrm{a}} \pm 0.35$ & 17.2 & 18.3 & $16.73^{\mathrm{b}} \pm 0.38$ & 15.3 & 17.5 & $14.97^{\mathrm{c}} \pm 0.23$ & 15.5 & 16.2 & $14.63^{\mathrm{c}} \pm 0.30$ & 14.2 & 15.4 & $\mathrm{P}<0.001$ & \\
\hline $\mathrm{NO}_{2}(\mathrm{mg} / \mathrm{kg})$ & $27.83 \pm 0.58$ & 27.2 & 29 & $25.70 \pm 0.20$ & 24.5 & 26.1 & $25.60 \pm 0.26$ & 25.2 & 25.8 & $24.70 \pm 1.27$ & 23.1 & 25.2 & $\mathrm{P}>0.05$ & \\
\hline $\mathrm{NO}_{3}(\mathrm{mg} / \mathrm{kg})$ & $27.47 \pm 0.27$ & 27.1 & 28 & $26.40 \pm 0.64$ & 24.3 & 26.7 & $25.30 \pm 0.36$ & 25.8 & 26.2 & $24.80 \pm 1.82$ & 21.2 & 25.6 & $\mathrm{P}>0.05$ & \\
\hline $\mathrm{SO}_{4}(\mathrm{mg} / \mathrm{kg})$ & $26.05^{a} \pm 0.48$ & 25.53 & 27.01 & $18.17^{\mathrm{c}} \pm 0.18$ & 17.83 & 18.46 & $18.11^{\mathbf{c}} \pm 0.50$ & 17.2 & 18.91 & $20.65^{\mathbf{b}} \pm 2.34$ & 17.5 & 25.23 & $P<0.001$ & \\
\hline Clay (\%) & $7.40 \pm 0.29$ & 6.9 & 7.9 & $6.53 \pm 0.24$ & 6.2 & 7.6 & $7.20 \pm 0.13$ & 7.1 & 7.5 & $7.17 \pm 0.43$ & 6.4 & 7.3 & $\mathrm{P}>0.05$ & \\
\hline Silt (\%) & $4.23 \pm 0.15$ & 4 & 4.7 & $3.97 \pm 0.03$ & 3.9 & 4.4 & $3.90 \pm 0.32$ & 3.2 & 4.3 & $3.80 \pm 0.21$ & 3.5 & 4.1 & $\mathrm{P}>0.05$ & \\
\hline Sand (\%) & $86.77 \pm 1.02$ & 84.9 & 88.4 & $88.56 \pm 30.67$ & 87.3 & 89.6 & $88.37 \pm 1.68$ & 83.2 & 89 & $88.13 \pm 1.72$ & 83.2 & 88.6 & $\mathrm{P}>0.05$ & \\
\hline $\mathrm{Fe}(\mathrm{mg} / \mathrm{kg})$ & $594.33^{a} \pm 16.07$ & 562.2 & 611.2 & $579.83^{\mathrm{a}} \pm 21.89$ & 536.2 & 604.8 & $348.10^{b} \pm 21.84$ & 511.2 & 586.8 & $293.50^{\circ} \pm 24.75$ & 261.9 & 342.3 & $P<0.01$ & \\
\hline $\mathrm{Mn}(\mathrm{mg} / \mathrm{kg})$ & $19.83^{\mathrm{a}} \pm 0.88$ & 18.2 & 21.2 & $15.14^{\mathbf{b}} \pm 0.48$ & 6.21 & 17.81 & $7.91^{\mathbf{c}} \pm 0.83$ & 3.32 & 12.8 & $4.91^{\mathrm{d}} \pm 0.08$ & 6.78 & 9.01 & $\mathbf{P}<0.01$ & \\
\hline $\mathrm{Zn}(\mathrm{mg} / \mathrm{kg})$ & $17.20^{\mathrm{a}} \pm 0.55$ & 16.2 & 18.1 & $15.43^{b} \pm 0.12$ & 14.2 & 16.6 & $12.70^{\mathbf{b}} \pm 0.21$ & 12.3 & 13 & $10.57^{\mathbf{c}} \pm 0.32$ & 10.2 & 11.6 & $P<0.01$ & $\begin{array}{l}140-720 \text { within } \\
\text { target }\end{array}$ \\
\hline $\mathrm{Cu}(\mathrm{mg} / \mathrm{kg})$ & $2.40^{\mathrm{a}} \pm 0.20$ & 2.2 & 2.8 & $2.20^{\mathrm{a}} \pm 0.15$ & 1.8 & 2.3 & $2.06^{\mathrm{a}} \pm 0.12$ & 1.9 & 2.1 & $1.17^{\mathbf{b}} \pm 0.09$ & 1 & 1.3 & $\mathbf{P}<\mathbf{0 . 0 1}$ & $\begin{array}{l}36-190 \text { within } \\
\text { target }\end{array}$ \\
\hline $\mathrm{Cr}(\mathrm{mg} / \mathrm{kg})$ & $0.48^{\mathrm{a}} \pm 0.03$ & 0.42 & 0.52 & $0.37^{\mathbf{b}} \pm 0.03$ & 0.34 & 0.43 & $0.32^{\mathbf{c}} \pm 0.01$ & 0.27 & 0.39 & $0.28^{c} \pm 0.03$ & 0.26 & 0.29 & $\mathbf{P}<\mathbf{0 . 0 1}$ & $\begin{array}{l}100-380 \text { within } \\
\text { target }\end{array}$ \\
\hline $\mathrm{Cd}(\mathrm{mg} / \mathrm{kg})$ & $0.20^{\mathbf{c}} \pm 0.02$ & 0.18 & 0.23 & $0.16^{\mathbf{c}} \pm 0.01$ & 0.15 & 0.17 & $0.35^{\mathrm{a}} \pm 0.03$ & 0.31 & 0.4 & $0.22^{b} \pm 0.02$ & 0.2 & 0.25 & $\mathbf{P}<\mathbf{0 . 0 1}$ & $\begin{array}{l}0.8-12 \quad \text { within } \\
\text { target }\end{array}$ \\
\hline $\mathrm{Pb}(\mathrm{mg} / \mathrm{kg})$ & $3.31^{\mathbf{a}} \pm 0.01$ & 2.29 & 3.53 & $3.17^{\mathbf{b}} \pm 0.02$ & 2.14 & 3.21 & $2.24^{\mathrm{c}} \pm 0.22$ & 2.87 & 3.63 & $1.07^{\mathrm{d}} \pm 0.05$ & 0.98 & 1.15 & $\mathbf{P}<0.01$ & $\begin{array}{l}85-530 \text { within } \\
\text { target }\end{array}$ \\
\hline $\mathrm{Ni}(\mathrm{mg} / \mathrm{kg})$ & $3.89^{\mathrm{b}} \pm 0.27$ & 2.2 & 3.11 & $4.46^{\mathrm{a}} \pm 0.04$ & 2.87 & 3.02 & $2.87^{\mathrm{c}} \pm 0.07$ & 2.78 & 3 & $2.23^{\mathrm{d}} \pm 0.25$ & 1.98 & 2.73 & $P<0.01$ & $\begin{array}{l}35-210 \text { within } \\
\text { target }\end{array}$ \\
\hline $\mathrm{V}(\mathrm{mg} / \mathrm{kg})$ & $3.36^{\mathbf{b}} \pm 0.12$ & 1.11 & 3.51 & $3.55^{\mathrm{a}} \pm 0.02$ & 1.51 & 3.59 & $2.68^{c} \pm 0.04$ & 1.63 & 2.75 & $1.41^{\mathrm{d}} \pm 0.04$ & 1.34 & 1.45 & $P<0.01$ & \\
\hline THC (mg/kg) & $19.49^{\mathrm{a}} \pm 0.86$ & 18.6 & 21.21 & $15.89^{\mathbf{b}} \pm 0.47$ & 15.21 & 16.8 & $15.31^{\mathbf{b}} \pm 1.07$ & 13.5 & 17.21 & $12.95^{\mathrm{c}} \pm 0.64$ & 12.3 & 14.22 & $P<0.01$ & \\
\hline
\end{tabular}

SAM-UROUPA, ER; OGBEIBU, AE 
Effects of Solid Waste Disposal on the Receiving Soil.....

Table 2: Comparison of mean values for physical and chemical parameters of soil sampled across the three distances in Benin metropolis using one -way ANOVA

\begin{tabular}{|c|c|c|c|c|c|c|c|c|c|c|}
\hline \multirow{2}{*}{ PARAMETER } & \multicolumn{3}{|l|}{$0-50 \mathrm{~m}$} & \multicolumn{3}{|l|}{$50-100 \mathrm{~m}$} & \multicolumn{3}{|l|}{$>100 \mathrm{~m}$} & \multirow{2}{*}{ P-Val } \\
\hline & Mean \pm SE & Min & Max & Mean \pm SE & Min & Max & Mean \pm SE & Min & Max & \\
\hline $\mathrm{pH}$ & $5.63 \pm 0.23$ & 5.1 & 6.1 & $5.48 \pm 0.13$ & 5.2 & 5.8 & $5.48 \pm 0.17$ & 5.2 & 5.9 & $\mathrm{P}>0.05$ \\
\hline $\mathrm{EC}(\mu \mathrm{S} / \mathrm{cm})$ & $712.5 \pm 129.3$ & 540 & 1090 & $701.50 \pm 102.4$ & 563 & 997 & $675.50 \pm 64.83$ & 583 & 860 & $\mathrm{P}>0.05$ \\
\hline Org. C. (\%) & $1.65 \pm 0.09$ & 1.48 & 1.9 & $1.69 \pm 0.10$ & 1.54 & 1.97 & $1.70 \pm 0.09$ & 1.54 & 1.87 & $\mathrm{P}>0.05$ \\
\hline T.N (\%) & $0.12 \pm 0.01$ & 0.1 & 0.14 & $0.13 \pm 0.01$ & 0.12 & 0.15 & $0.13 \pm 0.01$ & 0.12 & 0.14 & $\mathrm{P}>0.05$ \\
\hline EA (meq/100g of soil) & $0.33 \pm 0.05$ & 0.2 & 0.4 & $0.35 \pm 0.03$ & 0.3 & 0.4 & $0.35 \pm 0.03$ & 0.3 & 0.4 & $\mathrm{P}>0.05$ \\
\hline $\mathrm{Na}$ (meq/100g of soil) & $0.85 \pm 0.23$ & 0.48 & 1.47 & $0.86 \pm 0.19$ & 0.54 & 1.27 & $0.91 \pm 0.22$ & 0.43 & 1.32 & $\mathrm{P}>0.05$ \\
\hline $\mathrm{K}$ (meq/100g of soil) & $0.52 \pm 0.11$ & 0.21 & 0.74 & $0.52 \pm 0.10$ & 0.24 & 0.75 & $0.56 \pm 0.09$ & 0.32 & 0.74 & $\mathrm{P}>0.05$ \\
\hline $\mathrm{Ca}(\mathrm{meq} / 100 \mathrm{~g}$ of soil) & $3.38 \pm 0.73$ & 1.56 & 4.67 & $3.59 \pm 0.65$ & 2.1 & 4.83 & $3.40 \pm 0.67$ & 1.67 & 4.61 & $P>0.05$ \\
\hline $\mathrm{Mg}$ (meq $/ 100 \mathrm{~g}$ of soil $)$ & $0.68 \pm 0.05$ & 0.55 & 0.76 & $0.60 \pm 0.03$ & 0.53 & 0.67 & $0.61 \pm 0.02$ & 0.56 & 0.65 & $\mathrm{P}>0.05$ \\
\hline $\mathrm{Cl}(\mathrm{mg} / \mathrm{kg})$ & $385.0 \pm 77.3$ & 260 & 610 & $424.50 \pm 88.8$ & 276 & 682 & $426.00 \pm 60.15$ & 325 & 598 & $\mathrm{P}>0.05$ \\
\hline Av. $\mathrm{P}(\mathrm{mg} / \mathrm{kg})$ & $16.69 \pm 1.39$ & 14.5 & 20.5 & $16.63 \pm 1.54$ & 14.22 & 21.1 & $17.46 \pm 1.48$ & 14.72 & 20.7 & $\mathrm{P}>0.05$ \\
\hline $\mathrm{NH}_{4} \mathrm{~N}(\mathrm{mg} / \mathrm{kg})$ & $16.18 \pm 0.79$ & 14.5 & 18.2 & $15.98 \pm 0.47$ & 15.2 & 17.2 & $16.03 \pm 0.86$ & 14.2 & 18.3 & $\mathrm{P}>0.05$ \\
\hline $\mathrm{NO}_{2}(\mathrm{mg} / \mathrm{kg})$ & $25.60 \pm 1.26$ & 23.1 & 29 & $26.03 \pm 0.69$ & 24.5 & 27.2 & $26.25 \pm 0.46$ & 25.1 & 27.3 & $\mathrm{P}>0.05$ \\
\hline $\mathrm{NO}_{3}(\mathrm{mg} / \mathrm{kg})$ & $25.68 \pm 1.52$ & 21.2 & 28 & $26.15 \pm 0.66$ & 24.3 & 27.1 & $26.15 \pm 0.41$ & 25.4 & 27.3 & $\mathrm{P}>0.05$ \\
\hline $\mathrm{S}_{4}(\mathrm{mg} / \mathrm{kg})$ & $20.12 \pm 1.85$ & 17.5 & 25.61 & $21.71 \pm 2.12$ & 17.83 & 25.53 & $20.41 \pm 2.24$ & 17.2 & 27.01 & $\mathrm{P}>0.05$ \\
\hline Clay (\%) & $7.03 \pm 0.22$ & 6.4 & 7.4 & $7.48 \pm 0.25$ & 7 & 7.9 & $6.75 \pm 0.29$ & 6.2 & 7.5 & $\mathrm{P}>0.05$ \\
\hline Silt (\%) & $4.08 \pm 0.08$ & 3.9 & 4.2 & $3.78 \pm 0.19$ & 3.2 & 4 & $4.08 \pm 0.22$ & 3.5 & 4.5 & $\mathrm{P}>0.05$ \\
\hline Sand (\%) & $88.90^{\mathrm{a}} \pm 0.26$ & 88.4 & 89.6 & $87.53^{b} \pm 0.5$ & 86.3 & 88.7 & $84.65^{\mathbf{c}} \pm 0.97$ & 83.2 & 86.3 & $\mathbf{P}<0.01$ \\
\hline $\mathrm{Fe}(\mathrm{mg} / \mathrm{kg})$ & $496.9 \pm 81.53$ & 261.9 & 609.6 & $509.00 \pm 58.0$ & 342.3 & 611.2 & $505.95 \pm 76.92$ & 276.3 & 598.5 & $P>0.05$ \\
\hline $\mathrm{Mn}(\mathrm{mg} / \mathrm{kg})$ & $10.43 \pm 3.60$ & 6.1 & 21.2 & $9.60 \pm 3.51$ & 5.32 & 20.1 & $9.09 \pm 3.19$ & 3.32 & 18.2 & $\mathrm{P}>0.05$ \\
\hline $\mathrm{Zn}(\mathrm{mg} / \mathrm{kg})$ & $13.58 \pm 1.65$ & 10.3 & 18.1 & $13.40 \pm 1.04$ & 11.2 & 16.2 & $13.45 \pm 1.47$ & 10.2 & 17.3 & $\mathrm{P}>0.05$ \\
\hline $\mathrm{Cu}(\mathrm{mg} / \mathrm{kg})$ & $2.03 \pm 0.31$ & 1.3 & 2.8 & $1.88 \pm 0.25$ & 1.2 & 2.3 & $1.85 \pm 0.30$ & 1 & 2.3 & $\mathrm{P}>0.05$ \\
\hline $\mathrm{Cr}(\mathrm{mg} / \mathrm{kg})$ & $0.37 \pm 0.05$ & 0.27 & 0.5 & $0.35 \pm 0.04$ & 0.26 & 0.43 & $0.37 \pm 0.05$ & 0.28 & 0.52 & $\mathrm{P}>0.05$ \\
\hline $\mathrm{Cd}(\mathrm{mg} / \mathrm{kg})$ & $0.22 \pm 0.04$ & 0.15 & 0.33 & $0.26 \pm 0.05$ & 0.17 & 0.4 & $0.22 \pm 0.03$ & 0.16 & 0.31 & $\mathrm{P}>0.05$ \\
\hline $\mathrm{Pb}(\mathrm{mg} / \mathrm{kg})$ & $2.30 \pm 0.51$ & 1.15 & 3.63 & $2.21 \pm 0.43$ & 1.09 & 3.21 & $2.09 \pm 0.40$ & 0.98 & 2.87 & $\mathrm{P}>0.05$ \\
\hline $\mathrm{Ni}(\mathrm{mg} / \mathrm{kg})$ & $2.70 \pm 0.18$ & 2.2 & 3.02 & $2.77 \pm 0.26$ & 1.98 & 3.11 & $2.60 \pm 0.21$ & 1.98 & 2.87 & $\mathrm{P}>0.05$ \\
\hline $\mathrm{V}(\mathrm{mg} / \mathrm{kg})$ & $1.40 \pm 0.11$ & 1.11 & 1.63 & $1.56 \pm 0.07$ & 1.45 & 1.75 & $1.54 \pm 0.04$ & 1.44 & 1.65 & $\mathrm{P}>0.05$ \\
\hline $\mathrm{THC}(\mathrm{mg} / \mathrm{kg})$ & $15.30 \pm 1.45$ & 12.3 & 18.6 & $15.46 \pm 1.29$ & 12.33 & 18.65 & $16.96 \pm 1.55$ & 14.22 & 21.21 & $\mathrm{P}>0.05$ \\
\hline
\end{tabular}

Table 3: Comparison of mean rank for microbial assay of soil sampled across the four stations in Benin metropolis using Kruskal-Wallis tests

\begin{tabular}{|c|c|c|c|c|c|c|c|c|}
\hline \multirow[t]{2}{*}{ Parameter } & \multirow[t]{2}{*}{$\mathrm{N}$} & \multicolumn{4}{|c|}{ Dumpsites (mean rank) } & \multirow[t]{2}{*}{$\mathrm{df}$} & \multirow[t]{2}{*}{ Test value } & \multirow[t]{2}{*}{$\begin{array}{l}P \text {-value } \\
\text { Pats }\end{array}$} \\
\hline & & IKHUENIRO & COSTAIN & UGBIYOKO & OMAGHE & & & \\
\hline Bacteria counts $\left(\mathrm{x} 10^{2} \mathrm{cfu} / \mathrm{g}\right)$ & 12 & 2.33 & 5.50 & 8.67 & 9.50 & 3 & 7.527 & $\mathrm{P}>0.05$ \\
\hline Fungi counts $\left(\mathrm{x} 10^{2} \mathrm{cfu} / \mathrm{g}\right)$ & 12 & 2.67 & 6.00 & 8.50 & 8.83 & 3 & 5.749 & $P>0.05$ \\
\hline
\end{tabular}

Table 4: Comparison of mean rank for microbial assay of soil sampled across the three distances in Benin metropolis using Kruskal-Wallis tests.

\begin{tabular}{llllllll}
\hline Parameter & $\mathrm{N}$ & Distance sampling (mean rank) & df & Test value & P-value \\
\cline { 2 - 4 } & & $0-50 \mathrm{~m}$ & $50-100 \mathrm{~m}$ & $>100 \mathrm{~m}$ & & & \\
\hline Bacteria counts $\left(\mathrm{x} 10^{2} \mathrm{cfu} / \mathrm{g}\right)$ & 4 & 8.75 & 5.88 & 4.88 & 2 & 2.508 & $\mathrm{P}>0.05$ \\
Fungi counts $\left(\times 10^{2} \mathrm{cfu} / \mathrm{g}\right)$ & 4 & 9.50 & 4.62 & 5.38 & 2 & 4.331 & $\mathrm{P}>0.05$ \\
\hline \multicolumn{7}{c}{ Note: $P>0.05$ - Not Significant } \\
\hline
\end{tabular}

SAM-UROUPA, ER; OGBEIBU, AE 
A posteriori DMR test performed revealed that stations 1 and 2 were highly significant from stations 3 and 4 which were not significant from each other for available phosphorus were the lowest, while station 1 was highly significant from station 2 and, stations 3 and 4 which were not different from each other were the lowest for total nitrogen. Across the study distances, the highest $(17.46 \mathrm{mg} / \mathrm{kg})$ and lowest $(16.63$ $\mathrm{mg} / \mathrm{kg}$ ) mean values were recorded in $>100 \mathrm{~m}$ and $50-$ $100 \mathrm{~m}$ for available phosphorus and, $50-100 \mathrm{~m}(0.13 \%)$ and $0-50 \mathrm{~m}(0.12 \%)$ for total nitrogen respectively. There were no significant differences $(P>0.05)$ across the distances when tested with one-way analysis of variance for available phosphorus and total nitrogen respectively.

The exchangeable acidity (EA) was in the range of 0.27 to 0.40 which may be attributed to the moderately acidic $\mathrm{pH}$ of the soils. The mean concentration of 14.72 to 20.77 was recorded for available phosphorus in the soil and is considered to be moderate. This contributed to the good growth of plants as was observed. This is in par with Okoronkwo et al., 2006.

The Cation Exchange Capacity (CEC); Na, K, Ca and $\mathrm{Mg}$ is the amount of exchangeable cation per unit weight of dry soil that plays important role in soil fertility. Nigeria soils with cation content of $2 \mathrm{meq} / 100 \mathrm{~g}$ soils are considered for calcium and magnesium while $0.2 \mathrm{meq} / 100 \mathrm{~g}$ soils and above are adequate for potassium ion (Ogbonna et al., 2009). The cation exchange capacity is directly related to the capacity of adsorbing heavy metals since the adsorption behavior depends on combination of the soil properties and the specific characteristics of the element (Barry et al., 1995). From our soil studied, it reveals that all the $\mathrm{CEC}$ except $\mathrm{Mg}(\mathrm{P}>0.05)$ were highly significant $(\mathrm{P}<0.001)$ and recorded all their highest mean values at station 1 and lowest at station 4. The control station for CEC is in par with Ogbonna et al., (2009) reports of $0.2 \mathrm{meq} / 100 \mathrm{~g}$ soils and above being adequate for potassium soil. Since dump-site stations were all higher than the control station, it shows that there was more of organic carbon/matter decomposition which added to the soil as a result of the waste and thus, has nutrients than the control.

Iron contents in soil samples collected were highest and lowest in stations 1 and 4 respectively, with mean values of $(594.33 \mathrm{mg} / \mathrm{kg})$ and $(293.50 \mathrm{mg} / \mathrm{kg})$ respectively. A highly significant difference $(\mathrm{P}<0.01)$ was observed when tested with one-way analysis of variance. A posteriori DMR test performed revealed that stations 1 and 2 which were not different from each other were higher than station 3 , while station 4 was the lowest. Across the distances, the highest mean value $(509.00 \mathrm{mg} / \mathrm{kg})$ and lowest mean value $(496.88$ $\mathrm{mg} / \mathrm{kg}$ ) were recorded in $50-100 \mathrm{~m}$ and $0-50 \mathrm{~m}$ respectively. There was no significant difference $(\mathrm{P}$ $>0.05$ ) across the distances when tested with one-way analysis of variance. Across the study distances, the highest and lowest mean values were recorded in $50 \mathrm{~m}$ - $100 \mathrm{~m}(2.77 \mathrm{mg} / \mathrm{kg})$ and $>100 \mathrm{~m}(2.60 \mathrm{mg} / \mathrm{kg})$ for nickel and, $50 \mathrm{~m}-100 \mathrm{~m}(1.56 \mathrm{mg} / \mathrm{kg})$ and $0-50 \mathrm{~m}(1.40$ $\mathrm{mg} / \mathrm{kg}$ ) for vanadium respectively. There were no significant differences $(\mathrm{P}>0.05)$ across the distances when tested with one-way analysis of variance for nickel and vanadium respectively.

Results of total bacterial and fungal counts showed minimal differences ( $\mathrm{p}>0.05)$ across sampling stations (Table 3 ). The bacterial and fungal counts obtained from the results did not show a significant difference $(\mathrm{P}>0.05)$ between the test stations and the control station respectively (Table 4), although the mean ranks were highest in station 4 which is the control station. The reason for the test stations being lower than the control station could be related to the findings of Ayliffe (1992) and Oyeleke et al., (2008) that health care waste (which is also present in this dump-site waste as no sorting is carried out at present) do not seem to provide favourable media for the survival of pathogens, because they frequently contain antiseptics. Ikhajiagbe and Unuagbokhe (2013) reported that increase concentration of sodium ions in the soil in the form of sodium bicarbonate resulted in decrease microbial composition of both fungi counts and bacteria counts. The same was the result for total hydrocarbon and organic carbon in the soil.

Jager et al. (1989) and Oyeleke et al. (2008) reported the isolation of more bacterial (see appendix) from waste of different hospitals than was reported in this study. The high fungi count might be due to the fact that waste in these dump-sites are very rich in organic material as reported by Jager et al. (1989), Oyeleke et al. (2008). They also reported that fungi being heterotrophic organisms depend on the presence of organic material. Irene (1996) stated that during the wet season water can drain carrying these organisms to local surface water, ground water or the sea. The pathogens present in the wastes can leach out and contaminate ground water.

The dump-site at station 1 is older in age, occupies more plot of land and has more quantity of waste than all the other waste dump-site sampled. This explains to a greater extent why more than $90 \%$ of the soil parameters sampled were always highest in this station. $0-50 \mathrm{~m}, 50-100 \mathrm{~m}$ and $>100 \mathrm{~m}$ mean distances study for all soil parameters from the dump-sites were not significantly different $(\mathrm{P}>0.05)$ with the exception 
of sand which recorded a highly significant different $(\mathrm{P}<0.01)$ in the order of $(0-50 \mathrm{~m})>(50-100 \mathrm{~m})>$ $(>120 \mathrm{~m})$. This is explainable with what was earlier discussed that most waste dumped at the sites occupies more than $50 \%$ of the landmass study. This could be due to the way and manner wastes are being deposited, the altitude of the waste managers/waste truck drivers and the improper rate of maintenance of the dumpsites.

With the results of the heavy metal concentration in this study as presented, the dump-sites soils can be considered to be impacted/ slightly polluted by the presence of the waste dump-sites, since the concentration of heavy metals (except for Cadmium) in all the test stations were higher than the control station. The results show that the soils are moderately acidic which could favor the precipitation and mobilization of heavy metals (Bhattacharya et al., 2002). The results are similar to reports by other workers (Helmissari et al., 1995; Bamgbose et al., 1999; Rockszyk and Szerszen, 1988; Kabala and Singh, 2001) who worked on copper in scoot pine forests around a heavy metal smelter in Southwestern Finland; chemical fraction of cadmium, copper, nickel and zinc in contaminated soils; earthworm as bioindicator of heavy metal pollution in dump-site of Abeokuta City, Nigeria; accumulation of heavy metals in arable layer of soil in the protection zones of copper smelters; fractionation and mobility of copper, lead and zinc in soil profiles in the vicinity of copper smelter respectively.

Conclusion: The seepage of these heavy metals through the soils of the waste dump-sites in Benin Metropolis can infiltrate directly through unsaturated zones to cause severe pollution problems. Therefore, solid waste handling, controlling and monitoring techniques in Benin Metropolis must be geared towards achieving quality environmental condition for man to live in. This will go a long way to protecting natural resources, especially the soil that are degraded by these solid wastes.

\section{REFERENCES}

AOAC (1999). Methods of Analysis Association of Official Analytical Chemists, Washington DC326p.

APHA (2008). Standard Methods for the Examination of Water and Wastewater. American Public Health Association, Washington, D.CUSA874p

Achudume, AC; Olawale, JT (2007). Microbial Pathogens of Public Health Significance in Waste Dumps and Common Sites Institute of Ecology and Environmental Studies, Obafemi Awolowo University, Ile-Ife. Nigeria. Journal of Environmental Biology, 28 (1). : 151-154.

Anikwe, MAN (2000). Amelioration of a heavy clay loam soil with rice husk dust properties and maize yield. Bioresource Technol74: 169-173

Anikwe, MAN (2000). Amelioration of a heavy clayloam soil with rice husk dust and its effect on soil physical properties in Abakaliki Agroecological Zone SE. Nigeria. Environ. Edu. Info. 18:79-89.

Anikwe, MAN; Nwobodo, KCA (2001). Long term effect of municipal waste disposal on soil properties and productivity of sites used for urban agriculture in Abakaliki, Nigeria. Bioresources Technol. 83: 241-251.

Alloway, BJ; Ayres, DC (1997). Chemical principles of environmental pollution. Blackie Academic and Professional, 53-359.

Ayliffe G (1992). Control of Hospital Infection: $A$ Practical Handbook. $3^{\text {rd }}$ Edition London, Chapman \& Hall Medical. pp 6

Bamgbose, O; Odukoya, O; Arowolo, TOA (1999). Earthworm as bio-indicator of heavy metal pollution in dump-site of Abeokuta City, Nigeria. http/rbt.ots.ac.cr/revista/48-1/zoobamb.htm: p17.

Bhattacharya, P; Mukherjee, AB; Jacks, J; Nordqvist, $S$ (2002). Metal contamination experimental studies on remediation. The Science of Total Environment 290: 165-180.

Barry, GA; Chudek, PJ; Best, EK; Moody, PW (1995). Estimating sludge application rates on land based on heavy metal and phosphorus saption characteristics of soil. Water Resources, 29: 20312034.

Cheesebrough M (2001). District Laboratory Practice in Tropical Countries, part 2. Cambridge University Press, Cambridge355p.

Cowan, ST; Steele, KJ (1974). Manual for Identification of Medical Bacteria 2ndEd; Cambridge University Press, Cambridge, UK216p.

Gasu, MB; Ntemuse, UE (2011). Physico-chemical properties of soil under municipal solid waste 
dump sites in Ife East Local Government Area, Osun State, Nigeria. Syllabus Review, 2 (3). 106113.

Helmissari, HS; Fritze, T; Nieminen, P; Palmgre, M; Vanha-Mamamma, S (1995). Copper in scoot pine forests around a heavy metal smelter in Southwestern Finland. Water, Air, Soil Pollution: 85: 1727-1732.

Ideriah TJK; Omuaru, Vot; Adiukwu, Pu (2006). Soil quality around a solid waste dump-site in Port Harcourt, Nigeria. Afr. J. Ecol. 44: 388-395.

Ikhajiagbe, B and Unuagbokhe, AS (2013). Phytoassessment of an enhanced naturally attenuated oilpolluted soil after exposure to various concentrations of sodium bicarbonate solution. International Journal of Scientific Research in Environmental Sciences 1 (9). : 250 -262.

Irene MC (1996). Characteristics and treatment of leachates from domestic landfills. Environment International 22 (4). 433-442.

Jager, E; Xander, L; Ruden, H (1989). Hospital wastes communication: microbiological investigations of hospital waste from various wards of a big and of smaller hospitals in comparison to household refuse. Hygiene 188: 345-364.

Kabala, C; Singh, BR (2001). Fractionation and mobility of copper, lead and zinc in soil profiles in the vicinity of copper smelter. Journal of Environmental Quality 30:345-492.

Mbagwu, JSC (1989). Influence of cattle feed lot manure on aggregate stability, plastic limit and water Central Italy. Biological Wastes 28:257-269.

Mbagwu, JSC; Piccolo A (1990). Some physical properties of structural aggregator separated from organic waste-amended soil. Biological Waste 23:107-121.

Nigerian Institute of Safety Professionals 2003.Contractor Employee HSE Training Manual, Level 3, ECNEL Ltd, Port Harcourt, Nigeria.

Nkeki, FN (2013). Living near high-voltage power lines: GIS-based modelling of the risk in Nigeria's Benin region. Applied GIS 9 (1). , 1-20

Ogbeibu, AE; Chukwurah, NA; Oboh, IP (2013). Effects of open waste dump-site on its surrounding surface water quality in Ekurede-Urhobo, Warri, Delta State, Nigeria. Natural Environment 1 (1). : 1-16
Ogbonna, DN; Kii, BL; Youdeowei, PO (2009). Some Physico-Chemical and Heavy Metal Levels in Soils of Waste Dump-sites in Port-Harcourt Municipality and Environs. J. Appl. Sci. Environ. Manage. 13 (4). $65-70$.

Okecha SA (2000). Pollution and Conservation of Nigeria Environment' Afrique International Associates, Owerri, Nigeria.

Okoronkwo, NE; Odemelam, SA; Ano, OA (2006). Levels of Toxic Elements in Soils of Abandoned Waste Dump Site. African Journal of Biotechnology 5 (13). : 1241-1244.

Oyeleke, SB; Istifanus, N; Manga, SB (2008). The Effects of Hospital Solid Waste on the Environment. International Journal of Integrative Biology 3 (3). : 191

Piccolo, A; Mbagwu JSC (1997). Exogenous humic substances as conditions for the rehabilitation of degraded soils agro-foods industry Hi-Tech. March/April.

Rockszyk, E; Szerszen, L (1988). Accumulation of Heavy Metals in Arable Layer of Soil in the Protection Zones of Copper Smelters. RoczGlebozn 39:135-156.

Smith, CJ; Hopmans P; Cook, FJ (1996). Accumulation of $\mathrm{Cr}, \mathrm{Pb}, \mathrm{Cu}, \mathrm{Ni}, \mathrm{Zn}$ and $\mathrm{Cd}$ in soil following irrigation with untreated urban effluents in Australia Environmental Pollution 94 (3). : 317-323.

SSSA (1971). Instrumental methods for analysis of soil and plant tissue. Soil Science Society of America, Corporated, Wisconsin, U.S.A Pp27-32.

Taiwo, LB; Oso, BA (2004). Influence of composting techniques on microbial succession, temperature, $\mathrm{pH}$ in a composting municipal solid waste. African Journal of Biotechnology3: 239-243.

Wild, A (1995). Soil and the environment: an introduction. Cambridge University Press, 109-165.

Zhang, MK; Liu, ZY; Wang, H (2010). Use of single extraction methods to predict bioavailability of heavy metals in polluted soils to rice. Communications in Soil Science and Plant Analysis 41 (7): $820-831$. 